\title{
Intergenerational Correlation of Labor Market Outcomes
}

\author{
Nicolas Hérault ${ }^{*}$ and Guyonne Kalb \\ Melbourne Institute of Applied Economic and Social Research \\ The University of Melbourne \\ Melbourne, Victoria 3010 \\ Australia
}

\begin{abstract}
This paper contributes to the relatively limited literature on the correlation of labor market outcomes of parents and their children. This literature is relevant to the larger literature on intergenerational income mobility since correlation in intergenerational labor market outcomes is one of the potential factors contributing to the intergenerational correlation of permanent incomes. In this paper, we consider the time spent in unemployment by both sons and daughters, while accounting for the potential endogeneity of education. Using the Household, Income and Labour Dynamics in Australia (HILDA) data, we find evidence of a positive correlation of labor market outcomes between fathers and sons and, to a lesser extent, between mothers and daughters. In addition, the results reveal a significant relationship between parents' and children's education levels, indicating that there is an indirect association of parental education with their children's labor market outcomes through education.
\end{abstract}

JEL Classification: J62, J64, I21.

Keywords: labor market outcomes, unemployment, education, intergenerational correlation

*Corresponding Author: e-mail: nherault@unimelb.edu.au; Phone: +61 383442188

Fax: +6138344 2111 


\section{Introduction}

A substantial proportion of the literature on intergenerational mobility focuses on earnings or income, the aim being to estimate the elasticity (or correlation ${ }^{1}$ ) of permanent incomes between two generations. This correlation may be caused by a number of factors. Indeed, national and international studies have documented the existence of intergenerational correlation across a wide range of outcomes related to income such as labor market outcomes, welfare participation, education and economic status. ${ }^{2}$ This paper's first contribution is that it adds to the limited literature focusing on the correlation of labor market outcomes of parents and their children. ${ }^{3}$ It shows that the intergenerational correlation in unemployment spells contributes to the intergenerational correlation in permanent incomes.

Shedding light on the intergenerational correlation of labor market outcomes, such as unemployment spells, is important in the assessment of the elasticity of permanent incomes as existing studies use proxies for permanent income that mostly ignore unemployment spells. ${ }^{4}$ As a consequence, if there is intergenerational correlation of labor market outcomes, existing estimates of intergenerational income elasticities are downward biased. $^{5}$

A better understanding of the role of intergenerational correlation in the transmission of labor market outcomes from one generation to the next is also important for policy design. If intergenerational correlation plays a significant role in outcomes for the next generation, then in addition to designing

\footnotetext{
${ }^{1}$ The two measures are roughly equal provided the variances of the log earnings are similar for parents and their children.

2 See for example, O’Neill and Sweetman (1998) or Farré and Vella (2013) for labor market outcomes; Pacheco and Maloney (2003), Maloney, Maani and Pacheco (2003) or Beaulieu et al. (2005) for welfare participation; Österberg (2000), Corak (2006), Ermisch, Francesconi, and Siedler (2006), Blanden, Gregg and Macmillan (2007), Mocetti (2007), Nicoletti and Ermisch (2007), Raaum et al. (2007) or Justman and Krush (2010) for earnings and income; Carneiro, Meghir and Parey (2013), Casey and Dustman (2007) or Heineck and Riphahn (2009) for education; and Björklund, Jäntti and Solon (2007) or Currie and Moretti (2007) for economic status.

${ }^{3}$ The literature on the intergenerational correlation of welfare participation is much larger (see footnote 2). Although the two issues are related, they are not the same. Welfare recipients can be working, while being out of work does not necessarily imply being a welfare recipient. Other papers, such as Couch and Dunn (1997), are interested in the intergenerational correlation in hours of work rather than employment or labor force participation.

${ }^{4}$ See Blanden (2013) for a discussion of these measurement issues and for a recent review of the literature on intergenerational mobility.

${ }^{5}$ Mocetti (2007) mentions the downward bias of the intergenerational correlation arising from estimation based on homogenous samples.
} 
policies for the current generation of unemployed persons (which in itself has become more important as it potentially will affect outcomes for the next generation), more attention should be given to the children growing up with jobless parent(s).

Previous studies have found intergenerational correlation of labor market outcomes. In the UK, O’Neill and Sweetman (1998) found evidence of a correlation of unemployment patterns between fathers and their sons using a hurdle model. They mention its importance in terms of intergenerational income mobility. In the US, descriptive analyses by Altonji (1988) and Altonji and Dunn (1991) found a correlation in the time spent in unemployment between fathers and their sons, and between mothers and their daughters. They also found a weak intergenerational correlation in the hours worked, and a stronger intergenerational correlation in the hourly wage. Using various modeling techniques, Farré and Vella (2013) found that labor force participation was positively correlated between mothers and their daughters in the US. In their recent overview of a wide range of intergenerational studies, Black and Devereux (2010, p.50) do not review labor market outcomes explicitly but they discuss the role of job displacement in the context of intergenerational income mobility. Although findings are varied, they seem to indicate that the effect of job loss of parents extends to the labor market outcomes of their children, which may only be partly due to the direct effect of the income shock and seems likely to be directly related, at least to some extent, to the parents' labor market outcome after the job loss. In Australia, Cobb-Clark and Ribar (2012) found evidence that youth growing up in families with higher household incomes (who are more likely to contain working parents) have "better" young adult outcomes in terms of avoiding economic inactivity.

This paper considers the time spent in unemployment, for both sons and daughters. A second contribution of this paper is that we use a modeling approach accounting for both the potential endogeneity and intergenerational correlation of education. We estimate a two-equation model using the two-Stage Least Squares (2SLS) approach: the main equation (second stage) for the labor market outcome and a first-stage equation for the education outcome, which also enters the labor market 
outcome equation. In a sensitivity analysis, we estimate the two equations jointly as well, using the Full Information Maximum Likelihood (FIML) approach, explicitly estimating the correlation between the error terms in the two equations. ${ }^{6}$ Based on the Household, Income and Labour Dynamics in Australia (HILDA) data, the analyses account for the correlation of the respondent's and parental education, the correlation of the respondent's and parental labor market outcomes, and for the direct effect education may have on labor market outcomes, while allowing for the potential endogeneity of education. Controlling for the direct effects of parental education on the education of their children allows us to establish the contribution of intergenerational correlation of education to the intergenerational correlation of labor market outcomes. ${ }^{7}$ To identify the models, the parental education and occupational skill level are only included in the respondent's education equation. Tests presented in the results section confirm the validity of these instruments.

A final contribution is that our results constitute the first estimates of the intergenerational correlation of labor market outcomes in Australia. Much of the existing literature uses US or UK data. The Australian population has had access to an extensive universal income support system since 1945, which is not time limited. This means that Australians have been sheltered from the income effects of unemployment to a larger extent than the US population. The question is whether this also limited the impact on the next generation.

We find that even after controlling for education and other individual characteristics, there is a positive intergenerational correlation of labor market outcomes. The percentage of time spent in unemployment by male respondents is 2.74 percentage points higher if the father was unemployed for more than 6 months during the respondent's childhood. For females, the percentage of time spent in unemployment is 0.44 percentage points higher if the mother was not employed when the respondent was aged 14. Given the average predicted percentage of time in unemployment of 3.22

\footnotetext{
${ }^{6}$ In this regard, this paper extends the New Zealand analysis of Maloney, Maani and Pacheco (2003), which focuses on welfare participation, by explicitly allowing for correlation between the unobserved factors in the education and labor market outcome equations.

${ }^{7}$ Mocetti (2007) also recognizes the importance of education in earnings outcomes and explores the educational mobility separately in his paper. He finds a strong correlation between the father's and son's education.
} 
for males and 2.41 for females, these are large effects. Besides the association of fathers' and their sons’ labor market outcomes, and of mothers' and their daughters' labor market outcomes, there is little evidence of other (cross-gender) intergenerational correlations of labor market outcomes.

The paper is structured in the following way. Section 2 provides a description of the data and a brief overview of summary statistics is included in Section 3. The 2SLS model and its results are discussed in Section 4. Concluding remarks are provided in Section 5.

\section{The HILDA Data}

We use the seven waves (years 2001 to 2007) of the HILDA Survey which were available at the time of analysis. The HILDA is a representative sample from the general Australian population. The dependent variable in the analysis is the proportion of time unemployed since completing full-time education. This is calculated as the ratio of the time spent in unemployment (in years) since completing full-time education to the total time (in years) since completing full-time education. The time spent in unemployment is defined as time out of work, but in the labor force (which meant the respondent had to report he/she was looking for work).

Unfortunately, the total time (in years) since completing full-time education appears to be subject to measurement errors for those with tertiary education. The evidence from the HILDA suggests that the time since completing full-time education includes, in many cases, the time spent in tertiary education. ${ }^{8}$ As a result, the proportion of time unemployed since completing full-time education is underestimated for individuals with higher qualifications. However, the consequences of this underestimation are likely to be limited given that the time in unemployment is generally very low already for these individuals. Should this cause any bias in the estimation, it means that our estimate of the impact of tertiary education on the time spent in unemployment is a lower-bound estimate; that

\footnotetext{
${ }^{8}$ When deducting the time since completing full-time education from the current age of the respondent, an age of around 18 was frequently computed as the age of completing full-time education. This was the case even for those with a bachelor's degree or more (which would typically be completed at a minimum age of 20 or 21).
} 
is, the expected negative effect of education on the proportion of time in unemployment would be closer to zero if there was no bias.

To establish the presence of intergenerational correlation, information on labor market outcomes (LMOs) of the respondent's parents is required. We do not observe lifetime labor market outcomes (or labor market outcomes up to the same age) for all individuals. Instead, we use three sets of retrospective variables for the parents. First, information on the parents' labor force status when the respondent was 14 is collected in the HILDA survey. That is, respondents are asked whether their father and their mother were employed when they were 14 years old. This information is used as a proxy for the LMO of the respondent's parents, although this is only a snapshot of the parent's labor market outcome at that specific time. ${ }^{9}$ Second, additional LMO information is available for fathers. That is, the survey collects information on the presence of unemployment spells (which when put together were longer than six months in total) for the father during the period the respondent was growing up. From the raw data, it is evident that, for the father, the "more than 6 months unemployed” variable was more strongly correlated with the child's labor market outcome than the employment status at age 14. In addition, the former describes the outcome across the complete childhood period, whereas the “employed when the respondent was aged 14" variable describes one point in time. For these reasons, we only use the "more than 6 months unemployed" variable for fathers in the multivariate analyses.

Third, information on the education level of the respondent's parents is collected in wave five. Therefore, a condition of selection into the sample of analysis is that respondents participated in wave five of the HILDA. Little other detail is known about the parents, besides country of birth.

\footnotetext{
${ }^{9}$ A crosscheck carried out on a subsample of young respondents, for whom more comprehensive parental information is available, indicated that, overall, parental employment status when the respondent was aged 14 is a reasonable proxy to distinguish between parents with poor and good labor market histories. That is, although some detail is lost, the variation in the parent's labor market outcome measure is meaningful in terms of identifying differences between parents in outcomes. Of course, this is just an indication, since childhood was a relatively recent event for this subsample.
} 


\section{Summary statistics}

We use information from the last available wave in which the respondent was between 20 and 54 years of age. The upper age limit is chosen to exclude any potential (early) retirees from the sample. Because we are interested in the proportion of time in unemployment since completing full-time education, we also exclude those who were in full-time study in all waves. After these exclusions, the sample of analysis consists of 2,619 men and 3,069 women.

\subsection{Labor market outcomes}

Table 1 summarizes the proportion of time spent in unemployment since completing full-time education cross-tabulated with the parents’ LMOs. Means are computed using the population weights provided in the HILDA data. Standard errors are reported on the second row so that the significance of differences between groups can be assessed. Some subgroups contain very few observations (reported on the third row for each group).

Table 1 Average proportion of time unemployed since completing full-time education (in \%) by mothers' employment at age 14 and fathers' unemployment during childhood

\begin{tabular}{lrrrr}
\hline & $\begin{array}{r}\text { Mother was } \\
\text { employed }\end{array}$ & $\begin{array}{r}\text { Mother was not } \\
\text { employed }\end{array}$ & $\begin{array}{r}\text { Mother was } \\
\text { deceased }\end{array}$ & ALL \\
\hline MEN & & & & \\
\hline Sather was unemployed for 6 months or more & 7.1 & 8.5 & 6.4 & 7.7 \\
$\quad$ Standard error & $(1.7)$ & $(1.8)$ & $(1.5)$ & $(1.2)$ \\
$\quad$ No. of observations & 136 & 121 & 2 & 259 \\
\hline Father was not unemployed & 3.3 & 2.6 & 1.0 & 3.0 \\
$\quad$ Standard error & $(0.4)$ & $(0.2)$ & $(0.5)$ & $(0.3)$ \\
$\quad$ No. of observations & 1,234 & 1,063 & 24 & 2,321 \\
\hline ALL & 3.7 & 3.2 & 1.4 & 3.4 \\
Standard error & $(0.4)$ & $(0.3)$ & $(0.7)$ & $(0.3)$ \\
No. of observations & 1,370 & 1,184 & 26 & 2,580 \\
\hline & WOMEN & & & \\
\hline Father was unemployed for 6 months or more & 3.0 & 3.0 &. & 3.0 \\
$\quad$ Standard error & $(0.7)$ & $(0.5)$ &. & $(0.4)$ \\
$\quad$ No. of observations & 204 & 165 & 0 & 369 \\
\hline Father was not unemployed & 2.4 & 2.3 & 2.0 & 2.4 \\
$\quad$ Standard error & $(0.2)$ & $(0.2)$ & $(1.1)$ & $(0.2)$ \\
$\quad$ No. of observations & 1,398 & 1,233 & 25 & 2,656 \\
\hline ALL & 2.5 & 2.4 & 2.0 & 2.5 \\
$\quad$ Standard error & $(0.2)$ & $(0.2)$ & $(1.1)$ & $(0.1)$ \\
$\quad$ No. of observations & 1,602 & 1,398 & 25 & 3,025 \\
\hline Source: Authors' calculations wsing weighted data from HILDA & & & &
\end{tabular}

Source: Authors' calculations using weighted data from HILDA. 
Table 1 shows that a bad LMO of the father is positively correlated with their sons' and daughters' time spent in unemployment since completing full-time education, although the correlation is only statistically significant for sons. The proportion of time in unemployment for women appears to be independent of the LMO of their mothers, whereas for men having had an employed mother at age 14 is slightly positively correlated with the time in unemployment, although the difference between the two groups is not significant at the five per cent level. This counterintuitive positive association can be explained by the fact that the mother's employment is less an indication of potential advantage or disadvantage for their children than the father's employment is, especially for respondents who grew up a few decades ago when female labor force participation was less common. However, what is interesting is that there is a slight negative correlation with the mother's employment if the father was unemployed for 6 months or more during childhood (although again the difference is not significant).

\subsection{Control Variables}

The summary statistics of the variables used in the multivariate analyses are presented in Appendix Table A.1. All variables are binary except for age, number of children, number of waves with preschool-age children present in the household, number of waves with school-age children and the health index. The latter is an index ranging from 0 for very poor health to 100 for excellent health. The number of missing values is higher for the health index than for the other variables because it is derived from the answers in a self-completion questionnaire. In order to limit the number of missing values (and thus the number of respondents excluded from the sample), we used the health index derived from previous HILDA waves, if available, whenever the information was missing in the last available wave. 


\section{The modeling approach and results}

\subsection{The base model}

The model used to investigate the intergenerational correlation of labor market outcomes consists of a system of two equations: one equation for the proportion of time unemployed and a second equation for the education level. The model needs to allow for the endogeneity of education of the respondent, given that this is likely to be to some extent determined by the same (observed and unobserved) factors as later labor market outcomes, such as for example motivation or ability.

The central question investigated in this paper is whether the parents' labor market outcomes are affecting the respondent's labor market outcome directly and/or indirectly through education. Identification is achieved through adding explanatory variables that can be argued to affect education but not labor market outcomes. These variables are parental education and parental occupation. Regressions not included in this paper (but available from the authors upon request) confirm that the parents' education and occupation do not directly affect the labor market outcomes of their children but influence the children's education level. ${ }^{10}$ While the intergenerational correlation of education is well documented and does not come as a surprise, the association between parental occupation and the respondent's education (while controlling for parental education) calls for further explanation. This association seems most likely to work through parental income (a factor we cannot directly control for), as for a given education level, higher-skill occupation levels would be correlated with higher incomes, generating more resources to fund the education of their children. The validity of these instruments is tested formally in Section 4.3, which presents the results based on 2SLS regressions, and all tests are passed.

The model is thus represented by the following two equations:

\footnotetext{
10 The coefficients on parental education in the respondent's labor market outcome equation are not jointly significant. That is, we cannot reject the null hypothesis of these coefficients being equal to zero in this equation. Tests carried out on male and female models result in P-values that are all above 0.45. Similar tests for parental occupation lead to P-values all above 0.38. In contrast, Appendix Table B.1 shows that these variables are significant in the education equation.
} 
$L M O=X_{1} \cdot \beta_{1}+\beta_{11 \mathrm{p}} L M O_{\text {parents }}+\gamma E D U+\varepsilon_{1}$

$E D U=X_{2} \beta_{2}+\beta_{21 \mathrm{p}} L M O_{\text {parents }}+\beta_{2 \mathrm{ep}} E D U_{\text {parents }}+\varepsilon_{2}$

where equation (1) explains latent labor market outcomes (LMO). The variable used for latent labor market outcomes is the observed proportion of time in unemployment since leaving full-time education $\left(L M O^{*}\right)$. It is censored at the lower (0) and the upper bound (100), since no matter how bad someone’s chances are in the labor market, they cannot be unemployed for more than 100 per cent of the time, and no matter how good someone's labor market situation is they cannot be unemployed for less than 0 per cent of their time. Although in principle equation (1) should be estimated using a Tobit specification, we found that an OLS approach leads to nearly identical results.

Equation (2) explains education outcomes (EDU), where $E D U$ is also a latent variable, which is not observed directly. Instead, we observe discrete education outcomes $E D U^{*}$ which take the following six values (from low to high): less than Year 10, Year 10 or 11, Year 12, certificate, diploma or university degree. This type of dependent variable would require the use of an ordered Probit specification. Instead we approximate the level of education by computing the number of years of schooling from the schooling and qualifications attained. We can then estimate equation (2) by OLS as well. $^{11} \varepsilon_{1}$ and $\varepsilon_{2}$ are jointly normally distributed with mean 0 , variances $\sigma_{1}^{2}$ and $\sigma_{2}^{2}$, and correlation $\rho$.

$X_{1}$ and $X_{2}$ are two sets of individual characteristics which include the same variables except that $X_{2}$ includes the parents' occupational skill level while $X_{1}$ does not. Together with parents' education level, parents’ occupational skills serve as instruments in the first-stage equation. The coefficient $\beta_{11 p}$ represents the direct association of parents’ labor market outcomes with the labor market outcomes of their children while the indirect association of the parents' labor market outcomes through the

\footnotetext{
${ }^{11}$ In an alternative specification based on the six discrete education categories, we used the ordered Probit approach instead of OLS. This was found to leave the estimated coefficients of interest in the labor market outcome equation essentially unchanged.
} 
children's education level is captured through combining the relevant coefficient $\beta_{2 l p}$ with $\gamma$. In addition, the direct association of parents' labor market outcomes with the education level of their children is estimated through the coefficient $\beta_{2 l p}$, while controlling for the respondent's characteristics, parents’ occupational skill levels and parents' education ( $\left.E D U_{\text {parents }}\right)$.

In Section 4.3, equation (1) is first estimated without education using OLS, then the same equation is estimated including education, again using OLS under the assumption that education is exogenous. To allow for the potential endogeneity of education, we use a 2SLS approach in the third and final specification. ${ }^{12}$ The 2 SLS approach first estimates the education equation combining all variables contained in $X_{1}$ and $X_{2}$ in $X$ :

$E D U=X \beta+\beta_{2 l \mathrm{p}} L M O_{\text {parents }}+\beta_{2 \mathrm{ep}} E D U_{\text {parents }}+\varepsilon_{2}$

Then education ( $\widehat{E D U}$ ) is predicted based on equation (3) and $\widehat{E D U}$ is substituted for EDU in (1), before estimating (4) by OLS:

$L M O=X_{1} \beta_{1}+\beta_{1 \mathrm{p}} L M O_{\text {parents }}+\gamma \widehat{E D U}+\varepsilon_{1}$

These three specifications allow us to explore the role of education in the intergenerational correlation of labor market outcomes.

\subsection{Refinements}

Labor market outcomes may depend on the business cycle. First, the effect of parental labor market outcomes may differ depending on the business cycle at the time of measurement. The effect of the business cycle is ambiguous, since there are two possible effects. If the parent is not in employment when unemployment is low, then the effect on the child could be higher, since unemployment at such a time is a stronger indication of the parent's latent poor labor market position than unemployment during a recession. However, if unemployment rates are high at the time the parent is unemployed,

\footnotetext{
12 Equations (1) and (2) have also been jointly estimated using the FIML procedure, and the Tobit - ordered Probit specification. This showed that the error terms in the two equations are uncorrelated, and the marginal effects of parental LMOs remained largely unchanged (see Hérault and Kalb, 2008).
} 
the unemployment spell is likely to be longer than when unemployment rates are low. Therefore, the effect of a persisting lower income during childhood could be higher, reinforcing the intergenerational correlation. The actual effect needs to be determined empirically. Therefore, we consider the effect of the unemployment rate at the time parental labor market outcomes were recorded. ${ }^{13}$ For mothers, we use the female unemployment rate at the time the respondent was aged 14 (using the respondent's current age to work out the relevant year). For fathers, we use the average male unemployment rate from the birth year to the $17^{\text {th }}$ year of the respondent. These two rates of unemployment are interacted respectively with the labor market outcome of the mother and father.

Second, to allow for differences in macroeconomic circumstances at the time the respondents entered the labor market, we include the average national unemployment rate by gender over the years in which the respondent was aged 18 to 22 . This is motivated by findings in the literature showing that poor starts in the labor market such as unemployment have deleterious effects on subsequent labor market outcomes (see Organisation for Economic Co-operation and Development (OECD), 1998). ${ }^{14}$

Since we do not have life-time LMOs, we include the respondent's age as a set of dummy variables to control for the fact that unemployment is more prevalent among younger individuals. Finally, although we cannot control for the parent's age, their age range at the time of measurement is expected to be somewhat limited by the fact that we measure their labor market outcomes while the respondent was a child. Therefore, although we cannot include the parents' age in the analysis, the impact on the intergenerational correlation coefficient is expected to be limited since for most parents, the LMO is measured at their prime working age.

\footnotetext{
${ }^{13}$ Unemployment rates by gender are provided by the International Labour Office (ILO, 2008) for the period from 1969 to 2005 and by the Australian Bureau of Statistics (Series: 6204055001TS0001) for the period from 1966 to 1968 (not available by gender for this period). No information was available for 1965; instead we use the unemployment rate as it was in August 1966, which is the earliest data available from the ABS. This is a reasonable approximation since unemployment was very low and stable in those years. More detailed information by region is not useful since no information is available on where respondents lived in childhood, or when they were aged between 18 and 22.

${ }^{14}$ Controls for unemployment rates later in life are not included due to collinearity issues (in particular with the age dummies).
} 


\subsection{Estimation results}

Estimated key marginal effects of the OLS estimation of equation (1), with and without controlling for education, are presented in Table 2, together with the results from the 2SLS estimation of equations (3) and (4). Only the effects of parental labor market outcomes and education in the labor market outcome equation, the focus of this paper, are presented and discussed. ${ }^{15}$ The results from the first stage estimation of equation (3) are presented in Appendix Table B.1.

The marginal effects reported for the 2SLS model combine the direct and indirect (through education) effects of parents' LMO on the proportion of time in unemployment and they take the included interactions with unemployment rates into account. Marginal effects are computed as the average change, over the entire sample, in the predicted proportion of time in unemployment associated with a one-unit increase in the corresponding variable.

With the exception of Leigh (2007), most of the evidence for Australia is based on cross tabulations and other descriptive analyses (for example, Headey, Warren and Harding, 2006; or Pech and McCoull, 1998; 2000), and hence it offers no appropriate comparison to our results. ${ }^{16}$ However, we make a few comparisons to results from the international literature.

The first interesting result from Table 2 is that the estimation of the intergenerational correlation of labor market outcomes is barely affected by the inclusion of education as a control variable, independent of whether education is included as an exogenous variable (as in the OLS model) or as an endogenous variable as in the 2SLS model. This indicates that although education has a strong effect on labor market outcomes (as is evident from Table 2), this effect works through channels that are independent from those of the intergenerational correlation of labor market outcomes. In particular, the coefficient estimates of the education equation presented in Appendix Table B.1 show no evidence of a statistically significant association between the labor market outcomes of the

\footnotetext{
15 The complete set of coefficient estimates is available from the authors upon request.

${ }^{16}$ Leigh (2007) examined the intergenerational correlation of earnings for Australia using multivariate analysis and estimated an intergenerational earnings elasticity of about 0.2 to 0.3 using HILDA data with imputed earnings for parents.
} 
parents and the education of their children. As a result, the marginal effect of parental LMO when the indirect effect through education is excluded is very similar to the marginal effect including direct and indirect channels. See the rows labeled "direct effect only" and compare these with the results in the rows directly above them in Table 2.

Table 2 Selected marginal effects on the proportion of time spent unemployed since completing full-time education (unweighted) ${ }^{a, b}$

\begin{tabular}{|c|c|c|c|c|c|c|}
\hline & \multicolumn{2}{|c|}{$\begin{array}{l}\text { OLS eq. (1), } \\
\text { education is excluded }\end{array}$} & \multicolumn{2}{|c|}{$\begin{array}{l}\text { OLS eq. (1), } \\
\text { exogenous education }\end{array}$} & \multicolumn{2}{|c|}{$\begin{array}{c}\text { 2SLS model } \\
\text { (eq. (4); eq. (3) in } \\
\text { Appendix Table B.1) }\end{array}$} \\
\hline & $\begin{array}{c}\text { Marginal } \\
\text { effect }\end{array}$ & t-value & $\begin{array}{c}\text { Marginal } \\
\text { effect }\end{array}$ & t-value & $\begin{array}{c}\text { Overall } \\
\text { marginal } \\
\text { effect }^{c}\end{array}$ & z-value \\
\hline \multicolumn{7}{|l|}{ MEN } \\
\hline $\begin{array}{l}\text { Father was unemployed for more than } 6 \text { months } \\
\text { (direct effect only) }\end{array}$ & 2.804 & 5.212 & 2.773 & 5.306 & $\begin{array}{l}2.741 \\
2.766\end{array}$ & $\begin{array}{l}5.653 \\
5.320\end{array}$ \\
\hline $\begin{array}{l}\text { Mother was not employed at } 14 \\
\text { (direct effect only) }\end{array}$ & -0.081 & -0.247 & -0.086 & -0.267 & $\begin{array}{l}-0.182 \\
-0.088\end{array}$ & $\begin{array}{l}-0.589 \\
-0.272\end{array}$ \\
\hline Years of schooling & & & -0.525 & -6.975 & $-0.636^{d}$ & -2.823 \\
\hline Av. unemployment rate (18-22) & 0.294 & 1.305 & 0.345 & 1.544 & 0.304 & 1.346 \\
\hline Av. childhood male unemployment rate $(0-17)$ & 0.832 & 2.475 & 0.871 & 2.530 & 0.856 & 2.440 \\
\hline Female unemployment rate at age 14 & -0.004 & -0.020 & -0.001 & -0.006 & -0.009 & -0.043 \\
\hline \multicolumn{7}{|l|}{ WOMEN } \\
\hline $\begin{array}{l}\text { Father was unemployed for more than } 6 \text { months } \\
\text { (direct effect only) }\end{array}$ & 0.014 & 0.040 & -0.068 & -0.201 & $\begin{array}{l}-0.044 \\
-0.084\end{array}$ & $\begin{array}{l}-0.138 \\
-0.246\end{array}$ \\
\hline $\begin{array}{l}\text { Mother was not employed at } 14 \\
\text { (direct effect only) }\end{array}$ & 0.506 & 2.186 & 0.488 & 2.175 & $\begin{array}{l}0.436 \\
0.484\end{array}$ & $\begin{array}{l}2.008 \\
2.167\end{array}$ \\
\hline Years of schooling & & & -0.261 & -4.943 & $-0.312^{\mathrm{d}}$ & -2.169 \\
\hline Av. unemployment rate (18-22) & 0.233 & 1.481 & 0.297 & 1.886 & 0.244 & 1.557 \\
\hline Av. childhood male unemployment rate $(0-17)$ & 0.830 & 3.468 & 0.930 & 3.753 & 0.845 & 3.472 \\
\hline Female unemployment rate at age 14 & -0.030 & -0.214 & -0.034 & -0.253 & -0.032 & -0.239 \\
\hline Validity of the instruments in the 2SLS model & & & & & Men & Women \\
\hline F-test first stage & & & & & 21.03 & 30.75 \\
\hline Sargan overidentification test & & & & & 13.43 & 8.52 \\
\hline (with p-values) & & & & & 0.49 & 0.86 \\
\hline $\begin{array}{l}\text { Note: a) See Appendix Table B. } 1 \text { for the list of } \\
\text { effects are in percentage points. In the two OI } \\
\text { variables with interactions. Marginal effects acco } \\
\text { 'Av. childhood male unemployment rate }(0-17 \\
\text { unemployment rate at age } 14 \text { '. c) The marg }\end{array}$ & $\begin{array}{l}\text { ol variables, } \\
\text { marginal ef } \\
\text { interaction } \mathrm{b} \\
\text { the interact }\end{array}$ & $\begin{array}{l}\text { xcluding tl } \\
\text { cts are ide } \\
\text { tween 'Fatl } \\
\mathrm{n} \text { between }\end{array}$ & $\begin{array}{l}\text { e variables li } \\
\text { tical to the } \\
\text { er was unem } \\
\text { 'Mother was }\end{array}$ & $\begin{array}{l}\text { ted under il } \\
\text { oefficient e } \\
\text { loyed for } \mathrm{m} \\
\text { not employ }\end{array}$ & $\begin{array}{l}\text { struments. } \\
\text { timates exc } \\
\text { re than } 6 \mathrm{~m} \\
\text { d at } 14 \text { a }\end{array}$ & $\begin{array}{l}\text { Marginal } \\
\text { t for the } \\
\text { ths' with } \\
\text { 'Female } \\
\text { of each }\end{array}$ \\
\hline
\end{tabular}

One of the main results from Table 2 is that the labor market outcomes of the father are associated with the time in unemployment of their sons, whereas the association is not significant for their daughters. After controlling for a range of individual characteristics, and whether or not education is controlled for, men are still more likely to spend more time in unemployment if their father was unemployed for more than six months while they were growing up. This is in line with the UK study 
by O’Neill and Sweetman (1998) who find that the father's unemployment increases the incidence of the son's unemployment. They find that, on average, the duration of all unemployment spells from age 21 to age 31 increases by 3 months, or alternatively expressed, as a proportion of the ten years duration, by 2.5 percentage points for sons of fathers who were unemployed when the sons were 11 or 16 years old. This is comparable to the 2.74 to 2.80 (depending on the model used) percentage points increase that we find across men's working lifetimes. The underlying coefficients on unemployment rate and unemployment rate interacted with the father's LMO (not reported here) show that the influence of a father's poor LMO is reinforced by high unemployment rates at the time that this LMO was measured. For men whose father was unemployed for more than six months while growing up, the proportion of time spent in unemployment increases with each additional percentage point in the average unemployment rate during childhood. This finding may reflect the fact that if unemployment rates are high at the time the father was unemployed, the unemployment spell is likely to be longer (and the negative effect larger) than when unemployment rates are low.

Besides the association of fathers' and sons' LMOs, there is no significant association of men's LMOs with their mothers' LMOs nor is there any evidence of an association between women's LMOs and their fathers' LMOs. However, the results show an association of the LMOs of the mothers with those of their daughters. The proportion of time spent in unemployment by female respondents is 0.44 to 0.51 (depending on the model used) percentage points higher if the mother was not employed when the respondent was aged 14. Again, the underlying coefficients point towards an association contingent on the unemployment rate at the time the respondent was 14 (i.e. the time when the employment status of the mother is recorded). A mother's poor LMO is associated with a higher proportion of time unemployed for their daughters if the unemployment rate was high at the time the mother's LMOs was recorded. However, caution is required when interpreting this because part of this association may not be due to unemployment rates per se but to cohort effects. This is due to the fact that the female unemployment rate is the highest for the youngest cohorts, while it is always low for older cohorts. Therefore it is virtually impossible to disentangle the cohort 
and unemployment rate effects. Differences in intergenerational correlation for the different cohorts of daughters may occur because female employment rates have been increasing over time, so that the more recent the cohort, the more likely it is that a non-employed mother signals a mother's poor LMO rather than a voluntary withdrawal from the labor market. ${ }^{17}$

The average male unemployment rate during the respondent's childhood (i.e. from birth to age 17) is found to be associated with higher proportions of time spent in unemployment. For both men and women, each additional point in this childhood unemployment rate is associated with a 0.8 to 0.9 percentage point increase in the proportion of time spent in unemployment. This shows that bad labor market conditions during childhood, most likely through their association with parental income (even if not unemployed, parents may have to work in lower-skill and/or lower-wage jobs), are associated with poor LMOs later in life. For the oldest cohorts and for those with the lowest education levels, it is also possible that this childhood unemployment rate partly captures the state of the labor market at the time of their school-to-work transitions.

To some extent, the results also indicate that the average unemployment rate when the respondent was aged between 18 and 22 (at the time of their transition from education to the labor market) has a positive association with the proportion of time spent in unemployment since completing full-time education. However, the computed marginal effects are generally not significant.

As expected, the direct association of education with the time spent in unemployment is negative and significant for both men and women. The association is larger for men than for women. Rather than being unemployed, women with low education levels are perhaps more likely to leave the labor force if unsuccessful, as the results from a similar model for the proportion of time not in work indicate (see Hérault and Kalb, 2008).

Regarding the validity of the instruments, Table 2 clearly shows that the two sets of instrumental variables have a significant effect on the children's education level. The standard F-tests for the

\footnotetext{
${ }^{17}$ More information would be needed to disentangle the cohort and unemployment rate effects.
} 
strength of the instruments are passed, with values of 21.03 for males and 30.75 for females. The other requirement for validity of the instruments is that these variables are not correlated with the unobserved determinants of the respondent's LMOs. Since we have overidentifying restrictions, it is possible to perform overidentification tests following the approach described by Wooldridge (2002). These tests confirm the validity of the instruments with p-values from the Sargan (1958) test of 0.49 for males and 0.86 for females. This suggests that the parents' education levels and the parents' occupational skill levels are appropriate instruments for the education level of the respondent.

\section{Conclusion}

This paper focuses on the correlation of labor market outcomes of parents and their children, and investigates whether education is a factor in this correlation. The first finding is that the introduction of education and intergenerational correlation of education in the children's labor market outcome equation barely reduces the estimated intergenerational correlation of labor market outcomes, despite education being clearly important for the children's LMOs. Moreover, the analyses show that the labor market outcomes of men are associated with the labor market outcomes of their father. Even after controlling for a range of individual characteristics (and independent of whether education is controlled for), there is a positive intergenerational correlation of labor market outcomes. The proportion of time spent in unemployment by male respondents is 2.74 percentage points higher if the father was unemployed for more than 6 months during the respondent's childhood. Given the average proportion of time in unemployment of 3.22, this is a large correlation. This indicates that the social security system in Australia is not sufficient to fully protect the families of unemployed men against the negative effects of unemployment. Additional policies are required in this area.

The association with the proportion of time in unemployment appears to be of the same order of magnitude as found in the one comparable study for fathers and their sons for the UK (O'Neill and Sweetman, 1998). Besides the association of fathers' and their sons' labor market outcomes, the only

other evidence of intergenerational correlation of labor market outcomes is the (weaker) association 
between mothers' and their daughters' labor market outcomes. The proportion of time spent in unemployment by female respondents is 0.4 percentage points higher if the mother was not employed when the respondent was aged 14.

A possible explanation for these results is that parents, and in particular fathers, with better labor market outcomes and a higher level of education have a better knowledge of the labor market (and the education system) and/or better and larger networks, which facilitate the successful school-towork transition of their children and may affect employment later in life. Parents may also provide positive role models for their children. The result that men's labor market outcomes are correlated with those of their father, whereas for women the correlation with their mother's labor market outcome is more important than the correlation with the father's outcome, points towards genderspecific role models.

This result on intergenerational correlation of labor market outcomes reinforces the positive intergenerational correlation of income or earnings generally found in the literature. Estimates of income mobility are usually based on parents and children who are in work at the time of the survey. However, spells of unemployment are likely to affect individuals' permanent incomes negatively. Therefore, the positive correlation found in this paper suggests that the correlation in income found in many studies is likely to be an underestimation of the correlation of permanent income within the full population of parents and children, including those not in paid employment. For example, the estimated intergenerational earnings elasticity for Australia found by Leigh (2007) to be between 0.2 and 0.3 is likely to be a lower bound.

The results further suggest that policy measures that are successful in returning individuals with children to employment may have larger and more long-term benefits than just the direct individual benefits. There appears to be a potential for substantive flow-on effects to the children of these individuals. 


\section{Acknowledgments}

This research was commissioned by the Australian Government Department of Education, Employment and Workplace Relations (DEEWR) under the Social Policy Research Services Agreement (2005-09) with the Melbourne Institute of Applied Economic and Social Research. The paper uses the confidentialized unit record file from the Department of Families, Housing, Community Services and Indigenous Affairs (FaHCSIA's) Household, Income and Labour Dynamics in Australia Survey, which is managed by the Melbourne Institute of Applied Economic and Social Research. The views expressed in this paper are those of the authors alone and do not represent the views of the Minister for Families, Housing, Community Services and Indigenous Affairs, FaHCSIA, DEEWR or the Commonwealth Government. Additional funding to support this research was provided by the Faculty of Economics and Commerce, The University of Melbourne. We are grateful to Deborah Cobb-Clark, John Creedy, Dean Hyslop, Moshe Justman, Matthias Sinning, two anonymous referees and participants at the Intergenerational Workshop at the Australian National University for helpful comments and discussions. 


\section{Appendix A Summary statistics for the regression sample}

Appendix Table A.1: Summary statistics (unweighted results)

\begin{tabular}{|c|c|c|c|c|}
\hline \multirow{3}{*}{ Number of observations } & \multicolumn{2}{|c|}{ MEN } & \multicolumn{2}{|c|}{ WOMEN } \\
\hline & \multirow{2}{*}{$\begin{array}{l}\text { Mean } \\
2,58\end{array}$} & Std. Err. & \multirow{2}{*}{$\begin{array}{l}\text { Mean } \\
3,025\end{array}$} & Std. Err. \\
\hline & & & & \\
\hline Av. unemployment rate (18-22) & 5.84 & 0.05 & 6.93 & 0.04 \\
\hline Av. childhood unemployment rate (0-17) & 3.27 & 0.05 & 3.35 & 0.04 \\
\hline Female unemployment rate at age 14 & 5.60 & 0.06 & 5.71 & 0.06 \\
\hline Father unemployed for more than 6 months & 0.90 & 0.01 & 0.88 & 0.01 \\
\hline Father present at 14 & 0.89 & 0.01 & 0.87 & 0.01 \\
\hline Father deceased at 14 & 0.02 & 0.00 & 0.02 & 0.00 \\
\hline Mother present at 14 & 0.95 & 0.00 & 0.96 & 0.00 \\
\hline Mother deceased at 14 & 0.01 & 0.00 & 0.01 & 0.00 \\
\hline Mother employed at 14 & 0.53 & 0.01 & 0.53 & 0.01 \\
\hline Years of schooling & 13.13 & 0.04 & 12.82 & 0.04 \\
\hline$<$ Year 10 & 0.04 & 0.00 & 0.05 & 0.00 \\
\hline Year 10 or 11 & 0.14 & 0.01 & 0.21 & 0.01 \\
\hline Year 12 & 0.12 & 0.01 & 0.15 & 0.01 \\
\hline Certificate & 0.32 & 0.01 & 0.17 & 0.01 \\
\hline Diploma & 0.10 & 0.01 & 0.11 & 0.01 \\
\hline University & 0.28 & 0.01 & 0.31 & 0.01 \\
\hline Age & 42.9 & 0.18 & 42.6 & 0.17 \\
\hline English speaking migrant & 0.09 & 0.01 & 0.08 & 0.00 \\
\hline Non-English speaking migrant & 0.12 & 0.01 & 0.13 & 0.01 \\
\hline Health index (SF36) & 70 & 0.38 & 71 & 0.38 \\
\hline Education completed abroad & 0.04 & 0.00 & 0.04 & 0.00 \\
\hline Single & 0.24 & 0.01 & 0.25 & 0.01 \\
\hline Ever had a child & 0.74 & 0.01 & 0.81 & 0.01 \\
\hline Number of children & 1.78 & 0.03 & 1.93 & 0.02 \\
\hline Number of waves with preschool-age child(ren) & 1.29 & 0.04 & 1.36 & 0.04 \\
\hline Number of waves with school-age child(ren) & 2.16 & 0.05 & 2.69 & 0.05 \\
\hline \multicolumn{5}{|l|}{ Cohort: } \\
\hline 1976-1986 & 0.12 & 0.01 & 0.13 & 0.01 \\
\hline 1971-1975 & 0.13 & 0.01 & 0.13 & 0.01 \\
\hline $1966-1970$ & 0.16 & 0.01 & 0.16 & 0.01 \\
\hline 1961-1965 & 0.17 & 0.01 & 0.18 & 0.01 \\
\hline $1956-1960$ & 0.17 & 0.01 & 0.16 & 0.01 \\
\hline 1951-1955 & 0.14 & 0.01 & 0.14 & 0.01 \\
\hline $1947-1950$ & 0.11 & 0.01 & 0.10 & 0.01 \\
\hline
\end{tabular}




\begin{tabular}{|c|c|c|c|c|}
\hline & \multicolumn{2}{|c|}{ MEN } & \multicolumn{2}{|c|}{ WOMEN } \\
\hline & Mean & Std. Err. & Mean & Std. Err. \\
\hline Father's occupation (ANU4 scale/10) & 4.50 & 0.04 & 4.42 & 0.04 \\
\hline Mother's occupation (ANU4 scale/10) & 3.15 & 0.05 & 3.11 & 0.05 \\
\hline Mother's occupation missing & 0.20 & 0.01 & 0.20 & 0.01 \\
\hline \multicolumn{5}{|l|}{ Mother's education: } \\
\hline None & 0.13 & 0.01 & 0.16 & 0.01 \\
\hline High school & 0.47 & 0.01 & 0.43 & 0.01 \\
\hline Year 12 & 0.09 & 0.01 & 0.08 & 0.00 \\
\hline Employer & 0.10 & 0.01 & 0.11 & 0.01 \\
\hline Technical college & 0.09 & 0.01 & 0.11 & 0.01 \\
\hline Teachers College & 0.05 & 0.00 & 0.04 & 0.00 \\
\hline University & 0.07 & 0.01 & 0.08 & 0.00 \\
\hline \multicolumn{5}{|l|}{ Father's education: } \\
\hline None & 0.13 & 0.01 & 0.16 & 0.01 \\
\hline High school & 0.29 & 0.01 & 0.28 & 0.01 \\
\hline Year 12 & 0.05 & 0.00 & 0.05 & 0.00 \\
\hline Employer & 0.20 & 0.01 & 0.20 & 0.01 \\
\hline Technical college & 0.18 & 0.01 & 0.17 & 0.01 \\
\hline Teachers College & 0.02 & 0.00 & 0.02 & 0.00 \\
\hline University & 0.13 & 0.01 & 0.12 & 0.01 \\
\hline Number of siblings & 2.70 & 0.04 & 2.84 & 0.04 \\
\hline
\end{tabular}

\section{Appendix B First stage results}

\section{Appendix Table B.1: First-stage coefficient estimates of education equation (unweighted results} from 2SLS model)

\begin{tabular}{|c|c|c|c|c|}
\hline \multirow[b]{2}{*}{ Dependent variable: Years of schooling } & \multicolumn{2}{|c|}{ MEN } & \multicolumn{2}{|c|}{ WOMEN } \\
\hline & Coefficient & z-value & Coefficient & z-value \\
\hline Constant & 9.62 & 12.61 & 7.12 & 9.62 \\
\hline Av. unemployment rate (18-22) & 0.08 & 1.45 & 0.21 & 4.12 \\
\hline Av. childhood unemployment rate $(0-17)$ & 0.04 & 0.45 & 0.33 & 4.23 \\
\hline Female unemployment rate at age 14 & 0.00 & 0.06 & -0.01 & -0.23 \\
\hline Father was unemployed for more than 6 months & 0.09 & 0.37 & -0.31 & -1.54 \\
\hline $\begin{array}{l}\text { Father was unemployed for more than } 6 \text { months interacted with childhood } \\
\text { unemployment rate }\end{array}$ & -0.01 & -0.29 & 0.05 & 1.25 \\
\hline Mother was not employed at 14 & 0.02 & 0.14 & 0.12 & 0.73 \\
\hline Mother was not employed at 14 interacted with unemployment rate at 14 & 0.02 & 0.90 & 0.01 & 0.31 \\
\hline Father absent at 14 & -0.28 & -1.94 & -0.12 & -1.00 \\
\hline Father deceased at 14 & -0.31 & -1.20 & 0.05 & 0.18 \\
\hline Mother absent at 14 & -0.55 & -2.59 & -0.30 & -1.38 \\
\hline Mother deceased at 14 & 0.03 & 0.09 & -0.72 & -1.82 \\
\hline \multicolumn{5}{|l|}{ Age (21-29 is the reference group) } \\
\hline $30-34$ & 0.51 & 1.95 & 0.57 & 2.74 \\
\hline $35-39$ & 0.75 & 2.33 & 1.20 & 4.21 \\
\hline $40-44$ & 0.88 & 1.97 & 1.65 & 4.07 \\
\hline $45-49$ & 1.17 & 2.17 & 2.18 & 4.40 \\
\hline $50-53$ & 1.70 & 2.79 & 2.75 & 4.94 \\
\hline 54 & 1.51 & 2.38 & 2.95 & 4.94 \\
\hline English speaking migrant & 0.04 & 0.29 & 0.16 & 1.16 \\
\hline Non-English speaking migrant & 0.39 & 2.74 & -0.01 & -0.08 \\
\hline Education completed abroad & 1.06 & 4.59 & 1.28 & 6.38 \\
\hline Ever had a child & 0.13 & 0.94 & -0.26 & -1.98 \\
\hline
\end{tabular}




\begin{tabular}{|c|c|c|c|c|}
\hline \multirow[b]{2}{*}{ Dependent variable: Years of schooling } & \multicolumn{2}{|c|}{ MEN } & \multicolumn{2}{|c|}{ WOMEN } \\
\hline & Coefficient & z-value & Coefficient & z-value \\
\hline Number of children & -0.07 & -1.65 & -0.19 & -4.95 \\
\hline Single & -0.34 & -3.38 & 0.09 & 1.05 \\
\hline Partner not employed & -0.01 & -0.12 & -0.48 & -2.85 \\
\hline Health index (SF36) & 0.01 & 5.42 & 0.01 & 5.59 \\
\hline Number of siblings & -0.12 & -5.64 & -0.09 & -4.59 \\
\hline \multicolumn{5}{|l|}{ Instruments } \\
\hline Father's occupation (ANU4 scale/10) & 0.13 & 5.98 & 0.15 & 7.17 \\
\hline Mother's occupation (ANU4 scale/10) & 0.06 & 2.43 & 0.09 & 4.02 \\
\hline Mother's occupation missing & -0.15 & -1.05 & 0.04 & 0.30 \\
\hline \multicolumn{5}{|l|}{ Mother's education (none is reference group) } \\
\hline High school & 0.20 & 1.33 & -0.05 & -0.38 \\
\hline Year 12 & 0.21 & 1.08 & 0.17 & 0.98 \\
\hline Employer & 0.06 & 0.33 & 0.38 & 2.39 \\
\hline Technical college & 0.44 & 2.29 & 0.65 & 4.07 \\
\hline Teachers College & 0.73 & 2.99 & 0.80 & 3.55 \\
\hline University & 0.66 & 2.86 & 0.74 & 3.77 \\
\hline \multicolumn{5}{|l|}{ Father's education (none is reference group) } \\
\hline High school & 0.26 & 1.67 & 0.26 & 2.08 \\
\hline Year 12 & 0.85 & 3.69 & 0.64 & 3.30 \\
\hline Employer & 0.41 & 2.61 & 0.27 & 2.11 \\
\hline Technical college & 0.72 & 4.36 & 0.58 & 4.13 \\
\hline Teachers College & 0.74 & 2.51 & 0.74 & 2.53 \\
\hline University & 1.00 & 4.96 & 0.77 & 4.47 \\
\hline
\end{tabular}

Note: A z-value above 2.58 indicates significance below the $1 \%$ level, a z-value above 1.96 indicates significance below the 5\% level, and a z-value above 1.64 indicates significance below the $10 \%$ level.

\section{References}

Altonji, J.G. (1988) 'The Effects of Family Background and School Characteristics on Education and Labor Market Outcomes’, Mimeo, Northwestern University.

Altonji, J. G. and Dunn, T.A. (1991) 'Relationships Among the Family Incomes and Labor Market Outcomes of Relatives’, National Bureau of Economic Research, Working Paper 3724.

Beaulieu, N., Duclos, J.-Y., Fortin, B. and Rouleau, M. (2005) 'Intergenerational reliance on social assistance: Evidence from Canada', Journal of Population Economics, 18, 539-562.

Björklund, A., Jäntti, M. and Solon, G. (2007) ‘Nature and Nurture in the Intergenerational Transmission of Socioeconomic Status: Evidence from Swedish Children and Their Biological and Rearing Parents’, Discussion Paper No. 2665, IZA, Bonn, Germany.

Black, S.E. and Devereux, P.J. (2010) 'Recent Developments in Intergenerational Mobility', Discussion Paper No. 4866 IZA, Bonn, Germany. 
Blanden, J. (2013) 'Cross-Country Rankings in Intergenerational Mobility: A Comparison of Approaches from Economics and Sociology', Journal of Economic Surveys, 27(1), 38-73.

Blanden, J., Gregg, P. and Macmillan, L. (2007) ‘Accounting for Intergenerational Income Persistence: Noncognitive Skills, Ability and Education’, Discussion Paper No. 2554, IZA, Bonn, Germany.

Carneiro, P., Meghir, C. and Parey, M. (2013) 'Maternal Education, Home Environments and the Development of Children and Adolescents', Journal of the European Economic Association, 11(s1), 123-160.

Casey, T. and Dustmann, C. (2007) 'Intergenerational Transmission of Language Capital and Economic Outcomes’, Discussion Paper No. 3074, IZA, Bonn, Germany.

Cobb-Clark, D.A. and Ribar, D.C. (2012), 'Financial stress, family relationships, and Australian youths' transitions from home and school', Review of Economics of the Household, 10, 469-490

Corak, M. (2006) ‘Do Poor Children Become Poor Adults? Lessons from a Cross-Country Comparison of Generational Earnings Mobility', in J. Creedy and G. Kalb (eds.), Dynamics of Inequality and Poverty, Research on Economic Inequality, 13, 143-188.

Couch, K.A. and Dunn, T.A. (1997) 'Intergenerational Correlations in Labor Market Status A Comparison of the United States and Germany', The Journal of Human Resources, 32(1), 210-232.

Currie, J. and Moretti, E. (2007) 'Biology as Destiny? Short- and Long-Run Determinants of Intergenerational Transmission of Birth Weight', Journal of Labor Economics, 25(2), 231-263.

Ermisch, J., Francesconi, M. and Siedler, T. (2006) ‘Intergenerational Mobility and Marital Sorting', The Economic Journal, 116 (July), 659-679.

Farré, L. and Vella, F. (2013) 'The Intergenerational Transmission of Gender Role Attitudes and its Implications for Female Labor Force Participation’, Economica, 80(318), 219-247. 
Headey, B., Warren, D. and Harding, G. (2006) ‘Families, Incomes and Jobs: A Statistical Report of the HILDA Survey', Melbourne Institute of Applied Economic and Social Research, The University of Melbourne.

Heineck, G. and Riphahn, R.T. (2009) 'Intergenerational Transmission of Educational Attainment in Germany: The Last Five Decades’, Jahrbücher für Nationalökonomie und Statistik, 229(1), 36-60.

Hérault, N. and Kalb, G. (2008) ‘Intergenerational correlation of labor market outcomes’, Report commissioned by the Australian Government Department of Education, Employment and Workplace Relations (DEEWR). Available at http://melbourneinstitute.com/downloads/labour/2-07 Final Report.pdf (viewed on 20 June 2012).

International Labour Office (2008) ‘LABORSTA Labour Statistics Database’.

Justman, M. and Krush, A. (2010) 'Measuring Intergenerational Income Mobility over Time’, Department of Economics, Ben Gurion University, Israel.

Leigh A. (2007) ‘Intergenerational Mobility in Australia’, The B.E. Journal of Economic Analysis \& Policy: 7(2) (Contributions), Article 6. Available at: http://www.bepress.com/bejeap/vol7/iss2/art6.

Maloney, T., Maani, S. and Pacheco, G. (2003) 'Intergenerational welfare participation in New Zealand', Australian Economic Papers, 42(3), 346-362.

Mocetti, S. (2007) 'Intergenerational Earnings Mobility in Italy', The B.E. Journal of Economic Analysis \& Policy: 7(2) (Contributions), Article 5. Available at: http://www.bepress.com/bejeap/vol7/iss2/art5.

Nicoletti, C. and Ermisch, J. F. (2007) 'Intergenerational Earnings Mobility: Changes across Cohorts in Britain', The B.E. Journal of Economic Analysis \& Policy: 7(2) (Contributions), Article 9. Available at: http://www.bepress.com/bejeap/vol7/iss2/art9.

O’Neill, D. and Sweetman, O. (1998) ‘Intergenerational Mobility in Britain: Evidence from Unemployment Patterns’, Oxford Bulletin of Economics and Statistics, 60(4), 431-447. 
Organisation for Economic Co-Operation and Development (1998) 'Getting Started, Settling in: The Transition from Education to the Labour Market’, pp. 81-122 in Employment Outlook. Paris: OECD.

Österberg, T. (2000) ‘Intergenerational Income Mobility in Sweden: What do Tax-Data Show?', Review of Income and Wealth, 46(4), 421-436.

Pacheco, G. and Maloney, T. (2003) ‘Are the Determinants of Intergenerational Welfare Dependency Gender-Specific?’, Australian Journal of Labour Economics, 6(3), 371-382.

Pech, J. and McCoull, F. (1998) ‘Intergenerational Poverty and Welfare Dependence: Is there an Australian problem?' a paper presented at Changing families, challenging futures, the 6th Australian Institute of Family Studies Conference, Melbourne 25-27 November 1998.

Pech, J. and McCoull, F. (2000) 'Transgenerational welfare dependence: Myths and realities’, Australian Social Policy, issue 1, 43-67.

Raaum, O., Bratsberg, B., Røed, K., Österbacka, E., Eriksson, T., Jäntti, M. and Naylor, R. (2007) 'Marital Sorting, Household Labor Supply, and Intergenerational Earnings Mobility across Countries’, Discussion Paper No. 3037, IZA, Bonn, Germany.

Sargan, J. D. (1958) 'The estimation of economic relationships using instrumental variables', Econometrica, 26, 393-415.

Wooldridge, J. M. (2002) 'Econometric Analysis of Cross Section and Panel Data', The MIT Press, Cambridge, M.A. 


\section{University Library}

\section{- M M N E R VA A gateway to Melbourne's research publications}

Minerva Access is the Institutional Repository of The University of Melbourne

Author/s:

Kalb, G;Herault, N

Title:

Intergenerational correlation of labor market outcomes

Date:

2016-03-01

Citation:

Kalb, G. \& Herault, N. (2016). Intergenerational correlation of labor market outcomes. Review of Economics of the Household, 14 (1), pp.231-249. https://doi.org/10.1007/ s11150-013-9218-5.

Persistent Link:

http://hdl.handle.net/11343/123413 